\title{
ZIMBABWE'S FORESTRY COMMISSION AND THE QUEST FOR SUSTAINABLE DEVELOPMENT
}

\author{
Dr. Jemitias MAPIRA \\ Department of Geography and Environmental Science \\ Faculty of Agriculture and Natural Sciences \\ Great Zimbabwe University,Box 1235, Masvingo, Zimbabwe
}

\begin{abstract}
This paper examines how some Zimbabwean government departments/organizations have been involved in the management of natural resources with a view to achieving sustainable development (SD) at local and national levels. This includes the Forestry Commission (FC) which dates back to the colonial era. Zimbabwe's forest resources are governed by the Forest Act (Chapter 19:05) of 1996 (G.o.Z, 1996). The Act was proclaimed through an Act of parliament in 1949 and has been revised numerous times since its inception. Following the promulgation of the Act, a Forestry Commission was established in April 1954 in order to protect and conserve the country's forest resources including indigenous and exotic species. During the 1990s Ngamo Safaris was established with a view to generating income for the FC. Since then, Ngamo Safaris has boosted the commission's coffers and brought financial stability to the organization. Unlike other government departments, ministries and NGOs, the FC is now self-reliant due to its income-generating projects. As such, it has become a model in the execution of its statutory mandate. The FC has been involved in such activities as tree planting, land reclamation and soil control. It has also been supplying villagers with tree seedlings with a view to promoting SD at local and national levels. However, in spite of this invaluable contribution, the FC is under-staffed at district, provincial and national levels, which undermines its regular operations.
\end{abstract}

\section{KEYWORDS}

\section{FORESTRY COMMISSION, SUSTAINABLE DEVELOPMENT, ZIMBABWE}

\section{INTRODUCTION}

Since the publication of the Brundtland Commission report in 1987 SD has become a household concept at local, national and global levels (WCED, 1991). Before the advent of the new millennium, Zimbabwe did not have a comprehensive policy on the environment even though a National Conservation Strategy (NCS) existed (Lopes, 1996). The goal of the NCS was to promote 'the sustainable use of natural resources through integrating socio-economic and environmental issues in development programmes. However, the contentious issues in the NCS were linkages between land degradation and growth, water and energy. The strategy only worked as a framework to guide aspects of environmental and natural resources management' (G.o.Z, 2009:1).

As a follow-up to Agenda 21, the need to develop an environmental policy came to the fore (Lopes, 1996). Consequently the policy development process started in January 2003 and ended in November 2005 (G.o.Z, 2009). The aim of the resultant policy was to 'avoid irreversible environmental damage, maintain essential environmental processes, and preserve the broad spectrum of biological diversity so as to sustain the long term ability of natural resources to meet the basic needs of people, enhance food security, reduce poverty, and improve the general standard of living of Zimbabweans' (GoZ, 2009: i). A major advantage of the policy compared to the NCS was that it put the environment at the centre of economic activities and sought to reduce poverty as well as improving the quality of life in general.

Zimbabwe's environmental policy comprises six objectives according to the policy document (G.o.Z, 2009). Firstly, it is geared at biodiversity conservation, the maintenance of the natural resource base, and basic environmental processes to enhance environmental sustainability. Secondly, it seeks to promote equitable access to and sustainable use of natural and cultural resources with an emphasis on satisfying basic needs, improving people's standards of living, enhancing food security, and reducing poverty. Thirdly, it encourages sustainable development by optimising the use of resources and energy, and minimising irreversible environmental damage, waste production and pollution, through incorporating provisions for environmental assessment and management in all economic and development activities.

Fourthly, it promotes public participation and a sense of responsibility for the environment, environmental education and awareness, and by promoting environmentally sustainable lifestyles. 


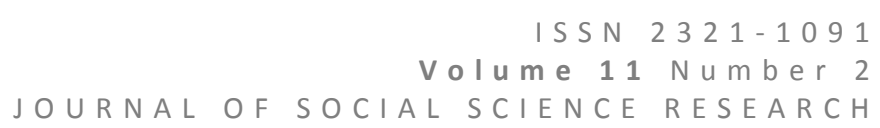

Furthermore it is geared at establishing and supporting an effective institutional framework, committed to sustainable development and able to collate and manage environmental information. Finally, it seeks to promote national interests by cooperating in drawing up and implementing international environmental agreements and collaborating with neighbouring countries on trans-boundary environmental issues.

In general, the policy is geared at the achievement of SD at local, national and global levels. However, in spite of this noble goal, most organisations which have an interest in environmental management and protection have not performed well as this paper will show. The only organisation which has achieved self-reliance in its daily operations is FC. Its duties (as outlined in the Forest Act CAP 19:05 of 1996) include: the implementation of all issues pertaining to forest matters, the control, management and exploitation of State forests, plantations and nurseries, the establishment, maintenance, improvement, renewal and exploitation of plantations and forest nurseries, the survey of the forest resources of Zimbabwe, and finally, conducting research and investigation into all matters pertaining to forest products. This paper examines the operations of the FC in the quest for SD at local and national levels. As a financially stable organisation, it sets an example to other government departments which are involved in environmental management in Zimbabwe and elsewhere in subSaharan Africa.

\section{RESEARCH METHODOLOGY}

This study is based on research methods, which include secondary and primary sources of information. Secondary sources included a literature review of various sources such as textbooks, journal articles, and government documents. This was followed by questionnaire surveys, which targeted the forestry commission and other organisations such as the environmental management agency (EMA), urban councils, the ministry of mines and mining development, the Agricultural, Technical and Extension Services (AGRITEX), non-governmental organisations (NGOs) and the department of parks and wildlife management (PWMA). Information derived from these sources was analysed and it yielded the views that are expressed in this paper.

\section{ORGANISATIONS WHICH LACK CAPACITY IN THE QUEST FOR SD}

As mentioned previously, various organisations are involved in environmental management activities in Zimbabwe. However, most of them have been ineffective in their efforts due to numerous challenges which confront them. Examples include: EMA, the Ministry of Mines and Mining Development, AGRITEX, the PWMA, urban councils /municipalities, and some NGOs.

\section{$E M A$}

EMA was established in 2007, some five years after the promulgation of the Environmental Management Act (CAP 20:27) of 2002 (G.o.Z, 2009). It was established through an Act of parliament to be an environmental watch dog at national level. The agency was formed through the merging of three government departments, which according to Chimhowu, Manjengwa and Feresu (2010), included: the Natural Resources Board (NRB), the Zimbabwe National Water Authority (ZINWA) Water Quality Section, and the Ministry of Health and Child Welfare's Hazardous Substances and Atmospheric Pollution Section. The NRB was established in 1941 as a department under the Ministry of Lands and Agriculture. Its mandate was to address issues of environmental protection and management at the national level (Lopes, 1996).

In order to achieve its goals, EMA is empowered to 'regulate, monitor and promote (the) sustainable management of natural resources and the protection of the environment with stakeholder participation' (www.ema.co.zw). It is expected to work in partnership with other government departments such as the FC, urban councils and municipalities, NGOs, commerce and industry. EMA has formulated five goals such as the creation of an enabling legal framework for improved environmental management. Secondly, it promotes a reliable and easily accessible environmental information system for decision making. Thirdly, it strives to develop into an effective, efficient and dynamic self-sustaining organisation which ensures a clean, safe and healthy environment and the sustainable use of natural resources. Finally, it seeks to promote environmental stewardship at all levels of society. This is achieved through the provision of environmental education (EE).

Over the years, EMA has been involved in several environmental management activities (G.o.Z, 2009). Firstly, it has promoted community participation in environmental issues at local, district, provincial and national levels. Secondly, it has forged partnerships with communities which have initiated environmental management and EE projects such as gardening and water harvesting. Thirdly, communities have realised more publicity of environmental crimes, which has led to the 
formation of environmental protection and management lobby groups in some parts of Zimbabwe such as Manicaland (Mapira, 2014). There has also been increased cooperation between EMA, some NGOs and the two ministries of education in the country. Furthermore, there has been improved coordination between EMA and traditional leaders such as chiefs and kraal heads in issues of environmental management. Since 2008, EMA's campaigns have led to an increase in the number of environmental impact assessments (EIAs) at local and national levels (EMA's Annual Reports 20092011). EMA has also been involved in ecosystem protection activities such as wetland protection, monitoring veldt fires, land degradation inspections, deforestation, sand and clay abstraction and transportation.

However, in spite of these achievements, EMA has faced several challenges in its operations (Chimhowu, et.al, 2010). Firstly, it is under-funded and therefore lacks capacity to efficiently execute its mandate. Secondly, it is under-staffed at national, provincial and district levels. As a result, its impact at the grassroots level is obscure (Mapira, 2012). The agency also lacks resources such as vehicles for transport and hence fails to cover remote parts of the country. Finally, due to a combination of the above challenges, EMA has failed to forge links with other government departments which have an interest in environmental protection and management. These include: the Ministry of Mines and Mining Development, Parks and Wildlife Management Authority (PWMA), Agricultural, Technical and Extension Services (AGRITEX) and some NGOs (Mapira, 2014). Those which it has made some partnerships with so far especially in tree planting and the dissemination of $\mathrm{EE}$ are the Forestry Commission (FC) and the formal education sector ( G.o.Z, 2003).

\section{The Ministry of Mines and Mining Development}

With over forty minerals, Zimbabwe has a vibrant mining industry which is one of the main pillars of its economy (Munowenyu, 1996). Mining falls under the Ministry of Mines and Mining Development while mining operations are governed by the Mines and Minerals Act (CAP 21:05) of 1996. The Act which dates back to the colonial era has been revised numerous times. The Ministry has several goals which according to Mapira (2014) include: promoting the sustainable exploitation of minerals, encouraging the prudent management of mining environments for the benefit of present and future generations, conducting inspections so as to ensure that mines comply with statutory regulations which govern mining operations, provision of explosives, permits and licences to mines, and encouraging the dissemination of EE and SD.

However, the industry faces several challenges in its operations (Mapira and Zhou, 2006). Firstly, it is a major cause of land degradation, air, water and noise pollution in the country. Secondly, after the depletion of minerals, some mines close down without reclaiming damaged environments. Thirdly, alluvial gold panning which is conducted by members of the informal sector has led to the siltation of rivers throughout the country. Fourthly, the use of mercury in gold panning has led to river pollution which endangers fresh water sources. Finally, some mines fail to benefit local communities or even reclaim damaged environments. The failure of EMA to forge links with the mining industry paints a bleak picture for environmental protection and management in the country.

\section{AGRITEX}

This department falls under the Ministry of Agriculture, Mechanisation and Irrigation. Its main activities include: training of farmers and providing advice and extension services, disseminating agricultural and market related information, mobilising farmers for targeted production, monitoring crops and livestock production trends at national, provincial and district levels, disseminating and promoting the adoption of new technologies through on-farm trial demonstrations, field days and exchange visits, and educating farmers and communities on how to care for their land, soil, water and other natural resources. For example from 2000 to 2011, AGRITEX managed to train some 6689 farmers in Masvingo Province only, which was a remarkable achievement (Mapira, 2014).

However, over the years the department has faced numerous challenges in its operations. These include: lack of transport for extension officers, shortage of resources such as computers at both district and provincial levels, and lack of accommodation for extension staff especially in resettlement areas (Chimhouwu, et.al, 2010). Other problems are: poor communication systems at all levels and a weak legislation on resource conservation. Most of these challenges are due to the under-funding of the department, an issue which should be addressed urgently. However, there are no easy solutions for this problem as it applies to most government departments (Mapira, 2012). 


\section{The PWMA}

The PWMA originated during the colonial era and its objectives include: wildlife conservation, environmental protection, and conservation, management and administration of wildlife resources in Zimbabwe. Its main activities include: conducting research on wildlife and environmental issues, conducting EIAs, assisting planning on wildlife development projects and providing technical and scientific advice to wildlife stakeholders (Mapira, 2014). The PWMA is affiliated to colleges which train some of its manpower. An example is the Mushandike College of Wildlife Management in Masvingo Province. It trains parks and wildlife employees and provides capacity building to all stakeholders. However, the department experiences several challenges which include: inadequate funds for its operations, research and outreach programmes, and shortages of vehicles for transport. There is also a lack of cooperation between it and EMA, the coordinating agent of environmental issues (G.o.Z, 2009).

\section{Urban Councils and Municipalities}

In addition to their numerous duties, urban councils and municipalities are also responsible for environmental management in their areas of jurisdiction. This includes waste disposal and as well as EE. These activities are usually conducted by the departments of environmental health which are found in every urban local authority (Jordan, 1984). In conducting EE campaigns, urban councils and municipalities often collaborate with EMA. Issues included in these campaigns are waste disposal and management, air, land and water pollution control, water, hygiene and sanitation, and health education. However, environmental health departments face several challenges in their regular operations.

Firstly, increasing population growth within towns and cities, lead to increases in quantities of waste which need to be disposed. Local authorities fail to cope with the ever increasing volumes of waste due to shortages of disposal equipment (Mapira, 2011). Secondly, the lack of waste disposal facilities such as landfills and dump sites is also a challenge. Consequently, some residents resort to the disposal of waste in un-designated places as previous studies have shown (Masocha and Tevera, 2002). Thirdly, some dump sites are not fenced, encouraging scavenging by dogs and some ordinary people as is the case in the city of Masvingo (Mapira, 2011). Finally, most waste disposal sites in Zimbabwe do not meet EMA's standards due to the lack of funds and resources in most local authorities. (G.o.Z, 2009).

\section{NGOs}

Some NGOs are involved in environmental management and SD projects in various parts of Zimbabwe (Lopes, 1996). Examples include: Environment Africa (EA), Zimbabwe Environment Law Association (ZELA), Africa 2000, and Environment and Development (ENDA). Others are also involved in natural resource conservation even though it is not their core business. This is because their main goal is poverty reduction and alleviation as exemplified by Care International, Christian Care and Caritas (Masvingo). Recently, Care International has trained 36734 farmers on conservation agriculture, 2900 on by-law formulation and enforcement while 16941 villagers were trained on environmental management techniques in including EE (Mapira, 2014). The training has also included the sustainable harvesting and marketing of non-timber forest products. The organisation has also been involved in activities such as conservation agriculture, establishing community gardens in rural areas, dam rehabilitation, agro-forestry, gulley rehabilitation and catchment protection. Some of the challenges it has faced over the years include political interference from some ruling party officials who regard it with suspicion (Mapira, 2012). In addition, there are no supportive grass roots structures for most NGOs operating in Zimbabwe. The NGO is also underfunded, which weakens its effectiveness in the execution of its mandate. There is also a shortage of publicity materials such as: brochures, posters and other forms of literature. Chronic droughts also increase the number of people who need support thereby weakening the effectiveness of the NGO's efforts.

Christian Care, just like Care International operates throughout Zimbabwe. Its goal is to enhance food security among vulnerable communities by training them on conservation farming. Targeting rural areas, the NGO has been operating in the country since the early days of independence in 1980. In Gutu District (Masvingo Province), some 1500 farmers have been trained in recent years and can harvest enough food even during drought years (Mapira, 2014). Its main challenges to date include resistance to change by some farmers and lack of experts who can train farmers on EE/environmental education for sustainable development (ESD). Since subsistence farmers are used to traditional farming methods, which are based on indigenous knowledge systems (IKS), they are reluctant to 
experiment with new approaches which they regard with suspicion. The NGO also lacks funds to hire experts who can train farmers on EE/ESD issues.

Caritas (Masvingo) is a donor NGO which is run by the Catholic Church in Zimbabwe. It targets rural and peri-urban communities in Masvingo Province. It is geared at alleviating hunger among the poor, promoting food security and empowering communities economically and socially so that they can respond to any risks. Its main achievements in recent years include: the establishment of demonstration plots for research, fields that increased yields, training communities in environmental issues, conservation, harvesting and tree planting in schools, educating communities on seed multiplication and preservation and educating communities on natural methods of farming which are environmentally friendly (Mapira, 2014).

Over the years Caritas has faced several challenges in its regular operations. Firstly, food insecurity often hampers projects aimed at achieving SD. Chronic droughts lead to the death of planted trees and crop seedlings while veldt fires destroy natural ecosystems. Secondly, the NGO is poorly funded, which undermines its regular operations such as EE/ESD campaigns. Thirdly, since EMA has weak linkages with civic organisations such as NGOs these campaigns have failed to develop to maturity. Finally, due to limited budgets among NGOs, follow-up on research recommendations is generally ineffective due to their lack of exposure.

\section{THE FC'S QUEST FOR SD IN ZIMBABWE}

As mentioned previously, the FC is a statutory body which falls under the Ministry of Environment and Natural Resources Management (FC Information Brochure, page 1). Its mandate is derived from the Forest Act (CAP 19: 05) of 1996 and the Communal Forest Produce Act (CAP 20) of 1987. The two Acts provide regulations for: the Forest Sector, Forestry Extension, Management of Gazetted Forests, Forestry Research and Training, and Income Generation. The main goal of the FC, according to its Information Brochure of 2012 (page 2) is to 'promote the sustainable management and development of the nation's socio-economic development through effective regulation and capacity enhancement in the sustainable utilisation and management of forest resources'.

At national level, the FC seeks to achieve three main objectives, namely: facilitating the improved supply and management of tree and forest resources at provincial and district levels, promoting the sustainable and economic use of tree and forest products in communal and resettlement areas, and providing EE to rural communities with a special focus on forestry issues. According to a recent study (Mapira, 2014: 160), the Masvingo branch of the FC defines EE as the creation of public awareness on the value of the environment including forests. It also views SD as a form of 'development that meets the needs of the present without compromising the ability of future generations to meet their own needs'. It goes on to define environmental education for sustainable development (ESD) as 'awareness raising that improves the quality of human life while living within the carrying capacity of supporting ecosystems'.

The activities of the FC at provincial level include: facilitating tree seedling production and tree planting, conducting farmer training workshops in forestry issues, production and distribution of information brochures, conducting awareness campaigns and commemorations on events such as the World Forestry Day (WFD) and the National Tree Planting Day (NTPD), and enforcing the forest legislation in conjunction with the police and traditional leaders. The WFD is celebrated around the world on 21 March every year. The day seeks to " (Forestry Commission Brochure, 2012, page 1). The day was adopted by the United Nations Food and Agriculture Organisation (FAO) in 1971 in order to 'provide opportunities for people to learn how forests can be managed and used sustainably for many purposes'. The aim of FAO was to increase public awareness of the importance of forests at local, national and global levels.

The Commission comprises three divisions, which include: Conservation and Extension, Forest Research and Training, and a Safari Business Trading Department known as Ngamo Safaris. Although EE/ESD is not its core business, the FC collaborates with EMA to provide it. This is accomplished in several ways such as: conducting environmental awareness campaigns at provincial and district levels, educating the public about the dangers of veldt fires, teaching people about the importance of tree planting, disseminating information on the value of indigenous trees, and training communities on how to grow trees such as gum trees and fruit trees, which have a socio-economic value.

The Conservation and Extension Division is responsible for the management of gazetted forests in the country (Matebeleland and Midlands Provinces). It has offices in all provinces and districts. Its main aim is to 'facilitate the improved supply and management of tree and forest resources 
throughout the country with emphasis on communal and resettlement areas' (FC Information Brochure, 2012 page 3). This is achieved by equipping communities with knowledge and practical skills on tree planting and management. The division has four goals, which guide its operations. Firstly, it seeks to reduce environmental degradation through seedling production and tree planting and World Forestry Day campaigns, concession supervision, development of woodland management plans, carrying out farm/area inspections, conducting anti-poaching patrols, organising publicity articles and conducting exhibitions, field days and training workshops.

Secondly, it strives to increase compliance with Forest Regulations through: organising workshops for staff and stakeholders publishing new regulations through the mass media, carrying out inspections to ensure compliance, issuing out forest produce movement permits, and accreditation of export companies. Thirdly, it seeks to increase Forestry contribution to the Gross Domestic Product (GDP) through: increased random checks at border posts, putting in place revenue collection systems, developing guidelines and proposals for main sources, supporting forest-based enterprises, and putting in place loss control measures. The fourth goal is directed at improved accountancy records of forest resources through: mapping of forest resources at district level, carrying out timber inventories in gazetted forests from destruction by fires, developing and maintaining game water supplies, conducting game counts, reviewing forest management plans for gazetted forests. In addition to the above tasks, the division has developed nurseries throughout the country in order to provide seedlings for a-forestation programmes. The nurseries supply both exotic and indigenous species as well as information on how to take care of the trees.

The Research and Training Division conducts research and forestry training for the national forestry sector. It is geared towards the development and management of forest resources. Its products include: research publications, improved seeds, information on the growth patterns of trees, their ecological requirements and skilled forestry personnel. The resultant knowledge, technology and expertise promote the sustainable management and utilisation of forest resources. The division comprises two wings, namely: Research, and Training. The research wing is further divided into two units, namely: Plantation Forestry and Social and Indigenous Forestry sectors. The two units are backed by the Technical Services Unit. The headquarters of the research unit is in Harare (Forest Research Centre). It also runs subsidiary branches near Stapleford in Chimanimani and Bulawayo as well as smaller research sites scattered throughout the country.

The training wing runs two colleges, namely: the Zimbabwe College of Forestry (ZCF), and the Forest Industries Training Centre (FITC). While the ZCF provides training in the management of forest resources, FITC offers training in primary wood processing. The two colleges offer certificate and diploma courses in addition to short courses for those already employed in industries. The colleges provide training opportunities at national level as well as the SADC region as a whole. From 1940 to 1979 (colonial era), they produced only 134 graduates compared to 868 after independence (19802012).

The division's mandate includes: conducting cost effective and client ordered research for the entire forestry sector in Zimbabwe, publish research results and develop technology for managing natural and plantation forests, and producing skilled labour for the national and SADC forestry sector through training at diploma and certificate levels as well as client oriented short in-service training. Research plays a key role in the country's forestry resources and their associated industries. It provides solutions for social, commercial and environmental problems at national, regional and global levels. Some of the major research programmes include: tree breeding seed physiology, plantation and indigenous silviculture, entomology, biometrics, and mapping and inventory services.

Financial stability is an important aspect of any organisation and the FC is not an exception. Ngamo Safaris was established in order to generate income for conservation programmes in the country's indigenous forest areas. This is done through recreational activities such as hunting and photographic safaris. Situated in the north western part of Zimbabwe, the facilities provide an opportunity of viewing flora and fauna in addition to hunting in a natural wilderness, which is rich in plant, animal and bird species. Due to its popularity at regional and global level, Ngamo Safaris has become a major source of revenue for the FC (FC Information Brochure, 2012). Achievements made in the past include: planting a total of .15 million trees at national level between 2011 and 2012, including the national tree planting day on the national calendar since 1981, encouraging individuals to establish commercial tree nurseries, developing small and medium enterprises (SMES) from timber utilisation, and publicising information on indigenous trees, the Tree of the Year concept (G.o.Z, 2009).

However, in spite of these achievements, the FC has encountered some challenges which include under-staffing. With only one officer per district, its operational capacity is greatly reduced. On the 
other hand, frequent electric power cuts, force people to resort to wood fuel for energy (Mapira, 2015). This in turn, encourages indiscriminate tree cutting in some areas. Possible solutions for these problems include: the promotion of alternative sources of energy such as solar. More resources should be channelled towards EE if positive results are to be realised, and continued networking with other organisations, which provide EE. A major strength of the FC is its ability to generate income through Ngamo Safaris. Unlike EMA and other organisations discussed in this paper, it is financially self-reliant, which is necessary for sustainable development. However, the under-staffing of the organization also reflects the lack of political will among policy makers. Although Zimbabwe is well known for drafting good environmental policies, its lack of commitment in the implementation of these policies has been a cause for concern since independence (Nkala, 1996). For example, although EIAs are mandatory, the country's Fast Track Land Reform Program (FTLRP) was never preceded by EIAs, which undermines environmental sustainability at local and national levels (Chimhowu, et.al, 2010).

\section{IMPLICATIONS FOR SD}

This paper has shown that the FC is the only government department which is financially stable in Zimbabwe. In the quest for SD, it is a role model to other organizations in the country. However, the government should recruit more staff in order to meet its manpower requirements. Its research branch is also quite effective, something which should be encouraged in other organizations. The formation of EMA as an environmental watch dog agency has been a notable achievement in Zimbabwe's quest for SD even though its lack of capacity to execute its mandate has been a cause for concern (Chimhowu, et.al, 2010). Due to its lack of visibility at the grass roots level, it has had little or no impact on environmental management. For example, over the years, environmental crimes such as land degradation, deforestation, veldt fire outbreaks, river pollution and the poaching of wildlife resources have been on the increase (Mapira, 2014).

As mentioned previously, EMA lacks both material and financial resources to execute its mandate. Due to low salaries, the department has lost experienced staff leading to inefficiency and the depletion of institutional memory, a necessary ingredient for any organization. The shortage of manpower at national, provincial and district levels is a cause for concern while the lack of vehicles for transport undermines the agency's operations especially in remote areas of the country. Furthermore, there is a need for the government to take environmental issues more seriously. In recent years, some top government officials have been involved in the poaching of elephants and rhinos and no legal action has been taken against them (Mapira, 2014).

Government should also respect its own laws on environmental protection. Failure to prosecute offenders reflects apathy at the policy implementation level. As mentioned previously, in the past the government has failed to conduct EIAs before embarking on its fast track land reform program even though the former are mandatory (Chimhowu, et.al: 2010). Given adequate funding, EMA could link up with other government departments, ministries and organizations which seek to promote environmental protection. These include: urban councils, the ministry of mines and mineral development, AGRITEX and NGOs in its quest for SD at national level. However, to date, owing to financial constraints, it has not been able to do so.

Furthermore, although the country's EE policy, which was promulgated in 2003 recommends the development of EE centers throughout Zimbabwe, to date none have been established, reflecting the lack of political will or commitment among policy makers (Mapira, 2012). Due to under-funding and under-staffing, EMA has failed to forge strong linkages with other organizations which have an interest in environmental protection and management such as the Ministry of Mines and Mining Development, AGRITEX, PWMA, urban councils/municipalities and some NGOs. The lack of coordination in environmental management issues at national, provincial, and district levels, is a major weakness in the country's quest for SD. In the past, fragmented approaches have proved to be counterproductive as reflected by conflicts among some ministries and government departments (Mapira and Mungwini, 2005). If EMA could be well-funded and better staffed, it would have the capacity to effectively play its role as the coordinating environmental management agency in the country. Unless these challenges are addressed, the future of environmental management in the country remains bleak.

\section{CONCLUSIONS}

Most organizations which are involved in environmental management and protection in Zimbabwe are not well equipped to effectively execute their mandate (Chimhowu, et.al: 2010). This is due to various factors including: under-funding, under-staffing and under-resourcing. Government departments 
generally lack the necessary capacity to achieve their set goals. Examples include: EMA, AGRITEX, PWMA, the Ministry of Mines and Mining Development, urban councils/municipalities and some NGOs. In the past, Zimbabwe has been criticized for failing to take environmental issues seriously (Lopes, 1996). Although it has a reputation of formulating very good policies, implementation has always been a major challenge. This has led to the under-performance of most government departments and ministries in the country's quest for SD. A notable exception however, is the FC, which has become financially self-reliant following the establishment of an income-generating department, Ngamo Safaris. The department is a role model as it has brought financial stability to the FC as a whole. However, in spite of this development, the department (FC) is still under-staffed, reflecting the government's lack of political will or commitment on environmental management issues. Government has also undermined some NGOs by interfering with their operations at various levels (Mapira, 2013). There is a need for it to improve its attitude towards these organizations if SD has to be achieved in the long run.

\section{REFERENCES}

Chimhowu, A. Manjengwa, J. and Feresu, S. 2010. Moving Forward in Zimbabwe: Reducing Poverty and Promoting Growth, Institute of Environmental Studies, University of Zimbabwe, Harare

EMA,s Annual Report 2009, Environmental Management Agency (EMA), Ministry of Environment and Natural Resources, Government of Zimbabwe (G.o.Z), Harare

EMA,s Annual Report 2010, Environmental Management Agency (EMA), Ministry of Environment and Natural Resources, Government of Zimbabwe (G.o.Z), Harare

EMA,s Annual Report 2011, Environmental Management Agency (EMA), Ministry of Environment and Natural Resources, Government of Zimbabwe (G.o.Z), Harare

EMA,s Annual Report 2012, Environmental Management Agency (EMA), Ministry of Environment and Natural Resources, Government of Zimbabwe (G.o.Z), Harare

FC Information Brochure, 2012, Forest Commission (FC), Harare

FC Information Brochure, 2012, World Forestry Day, Harare

G.o.Z 1987. The Communal Forest Produce Act (CAP 20) Government of Zimbabwe (G.o.Z), Government Printer, Harare

G.o.Z 1996. The Forest Act (CAP 19:05) Government of Zimbabwe (G.o.Z), Government Printer, Harare

G.o.Z 1996. The Mines and Minerals Act (CAP 21: 05) Government of Zimbabwe (G.o.Z), Government Printer, Harare

G.o.Z 2003. Zimbabwe National Environmental Education Policy and Strategies, Ministry of Environment and Tourism, Government of Zimbabwe (G.o.Z), Harare

G.o.Z 2009. National Environmental Policy and Strategies, Ministry of Environment and National Resources, Government of Zimbabwe (G.o.Z), Harare

Jordan, J.D.1984. Local Government in Zimbabwe: An Overview, Mambo Press, Gweru

Lopes, C. (ed)1996. Balancing Rocks: Environment and Development in Zimbabwe, SAPES Books, Harare

Mapira, J. and Mungwini, P. 2005 'River pollution in the city of Masvingo: A complex issue', Zambezia Vol. 32. Nos i/ii: 95-106

Mapira, J. and Zhou, TM.2006. 'From a mining settlement to a police camp: Buchwa Mine's Quest for survival', Zimbabwe Journal of Geographical Research Vol. 1 No1: 48-59

Mapira, J. 2011. 'Challenges of Solid Waste Disposal and Management in the city of Masvingo, Zimbabwe', Journal of Social Development in Africa, Vol. 26 No2: 67-91

Mapira, J. 2012. 'Zimbabwe's Environmental Education Policy and the Quest for sustainable development', Journal of Sustainable Development in Africa' Vol.14 No 6: 195-208

Mapira, J. 2013. 'Challenges of Zimbabwe's Media in the Provision of Environmental Education', Journal of Sustainable Development in Africa' Vol. 15 No 6: 1-15 
Mapira, J. 2014. 'Zimbabwe's Environmental Education Programme and its implications for sustainable development', Unpublished PhD Thesis, Curriculum Studies Department, Faculty of Education, Stellenboch University, Stellenbosch

Mapira, J. 2015. 'Air Pollution in Zimbabwe: An Environmental Health Challenge' Journal of Social Science Research Vol 9 No 1:1750-1758

Munowenyu, E. 1996. A-Level Geography: A Comprehensive Guide, Longman, Harare

Nkala, D. 1996. In Lopes, C. (ed) Balancing Rocks: Environment and Development in Zimbabwe, SAPES Books, Harare

WCED, 1991. Our Common Future: World Commission on Environment and Development (WCED), Oxford University Press, Oxford

www.ema.co.zw

\section{*ABOUT THE AUTHOR}

Jemitias MAPIRA (PhD) is an associate professor in Geography and Environmental Science at Great Zimbabwe University in the city of Masvigo (Zimbabwe) where he has been employed since 2003. He is a human geographer and environmental scientist and has published extensively in his areas of research interest.

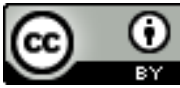

This work is licensed under a Creative Commons Attribution 4.0 International License.

DOI:10.24297/jssr.v11i2.6305 